\title{
Evaluation of the antibacterial effects of essential oil from the leaves of Laurus nobilis L. in Kerman Province
}

\author{
M. Moghtader* and A. Farahmand \\ Department of Biodiversity, Institute of Science and High Technology and Environmental Sciences, \\ Graduate University of Advanced Technology, Kerman, Iran.
}

Accepted 22 January, 2013

\begin{abstract}
The antibacterial activity of the essential oil of Laurus nobilis L. on human pathogenic bacteria by disc diffusion method via average inhibition zone was studied. The chemical composition of the essential oil of the leaves of $L$. nobilis L. (Lauraceae) were obtained by hydrodistillation method and analyzed by gas chromatography (GC) and gas chromatography mass spectrometry (GC/MS). Thirty three compounds, accounting for $95.75 \%$ of the total oil with $1.8 \%(\mathrm{v} / \mathrm{w})$ oil yield were identified in the essential oil of the leaves. The major components were 1,8-cineole (25.7\%), sabinene $(8.7 \%)$ and $\alpha$-pinene $(5.25 \%)$. To study the antibacterial activity, the essential oil tested against 9 bacteria strains such as three Gram positive bacteria: Staphylococcus aureus, Staphylococcus epidermidis and Streptococcus faecalis and six Gram negative bacteria: Pseudomonas aeroginosa, Shigella flexneri, Klebsiella pneuomoniae, Salmonella typhi, Serratia marcescens and Escherichia coli were studied. Effect of the essential oil of $L$. nobilis on bacteria tested was more than that of tetracycline antibiotic. The results showed that the essential oil of $L$. nobilis had strong anti-bacterial effects.
\end{abstract}

Key words: Laurus nobilis L., human pathogenic bacteria, antibacterial activity, 1,8-cineole, gas chromatography mass spectrometry (GC/MS).

\section{INTRODUCTION}

Pathogenic bacteria are important causes of disease in humans and farm products. Pathogenic bacteria contribute to other global important diseases, such as pneumonia, which can be caused by bacteria such as Streptococcus and Pseudomonas, and foodborne illnesses, which can be caused by bacteria such as Shigella and Salmonella. Side effects of drugs, use of chemical preservatives and the use of a special blend of natural oils to prevent the growth of bacteria need to be researched on. Sweet bay or bay laurel with scientific name, Laurus nobilis L. (Lauraceae) is an evergreen shrub growing to $12 \mathrm{~m}$ (39ft) by $10 \mathrm{~m}(32 \mathrm{ft})$ at a slow rate and indigenous to the south parts of Europe and Mediterranean area. It is hardy to zone 8. Its leaf appears in January and flower from April to May. The flowers are

\footnotetext{
*Corresponding author. E-mail: moghtader18@yahoo.com.
}

dioecious (individual flowers are either male or female, but only one sex is found on any plant; so both male and female plants must be grown if seed is required) and are pollinated by bees. The plant is not self-fertile. Leaves are fresh or dried. As a spice, with aromatic flavouring, bay leaves are commonly used as flavouring for soups, stews, etc and form an essential ingredient of the herb mix 'Bouquet Garni' (Huxley, 1992). This plant is cultivated in the northern part of Iran. In folk medicine, the leaves of this plant are used to treat epilepsy, neuralgia, Parkinsonism, hemorrhoid and rheumatic pains (Weiss and Fintelmann, 2000). The leaves can be used either fresh or dried after summer harvesting and drying. The flavour of freshly dried, crushed or shredded leaves of the plant is stronger than that of fresh leaves, but the leaves should not be stored longer than a year since they will lose their flavour (Bown, 2001). The dried fruit is used as flavouring. The dried leaves are brewed into herbal tea. An essential oil obtained from the leaves is used as food 
flavouring. Yields can vary from 1 to $3 \%$ oil (Chiej, 1984). The bay tree has a long history of folk use in the treatment of many ailments, particularly as an aid to digestion and in the treatment of bronchitis and influenza (Phillips and Foy, 1990). It has also been used to treat various types of cancer (Duke et al., 2002). The fruits and leaves are not usually administered internally, other than as a stimulant in veterinary practice, but were formerly employed in the treatment of hysteria, amenorrhoea, flatulent colic, etc (Bisset and Wichtl, 2001). It is also reported that the leaves are used mainly to treat upper respiratory tract disorders and to ease arthritic aches and pains (Barnes et al., 2002). It is settling to the stomach and has a tonic effect, stimulating the appetite and the secretion of digestive juices. The leaves are antiseptic, aromatic, astringent, carminative, diaphoretic, digestive, diuretic, emetic in large doses, emmenagogue, narcotic, parasiticide, stimulant and stomachic. The fruit is antiseptic, aromatic, digestive, narcotic and stimulant. An infusion has been used to improve appetite and as an emmenagogue (Grieve, 1984). The fruit has also been used in making carminative medicines and was used in the past to promote abortion. A fixed oil from the fruit is used externally to treat sprains, bruises etc, and is sometimes used as ear drops to relieve pain (Grieve, 1984). The essential oil from the leaves has narcotic, antibacterial and fungicidal properties (Lewis et al., 2003). An essential oil from the fruit is used in soap making. The plant is highly resistant to pests and diseases, it is said to protect neighbouring plants from insect and health problems (Holtom and Hylton, 1979). The leaves are highly aromatic and can be used as an insect repellent, the dried leaves protect stored grain, beans, etc from weevils. It is also used as a strewing herb because of its aromatic smell and antiseptic properties (Chiej, 1984). Very tolerant of clipping, it can be grown as a screen or hedge in areas suited to its outdoor cultivation. Wood-sweetly-scented, does not wear quickly. Used for marqueterie work, walking sticks and friction sticks for making fires. The antibacterial activity of essential oil of the leaves of $L$. nobilis $L$. plant has been studied in other countries and in Iran but the antibacterial of the essential oil of the leaves of $L$. nobilis $\mathrm{L}$. that grow in Kerman Province has not yet been studied.

In the present work, the antibacterial properties of the oil of the leaves of L. nobilis L. that grows in Kerman Province in Iran were studied and then the results were compared with others from other countries.

\section{MATERIALS AND METHODS}

\section{Plant material and isolation procedure}

The leaves of $L$. nobilis L. plant were obtained from plants grown in a village in Kerman Province, Iran at full flowering stage in April 2011. The samples were cleaned in shade condition to prevent hydrolyzation of the existing materials and to keep the natural color the help of Clevenger set for three hours. The obtained essential oils were dried with anhydrous sodium sulfate and kept in sterile sample tubes in refrigerator. The oil yields from leaves was calculated as dry weight percentage, $1.8 \%(\mathrm{v} / \mathrm{w})$.

\section{Analysis of essential oil}

\section{Gas chromatography}

GC analysis was performed using a model HP-439 gas chromatograph equipped with column CP Sil. 5CB with $25 \mathrm{~m}$ length, internal diameter of $0.25 \mathrm{~mm}$ and film thickness of $0.39 \mu \mathrm{m}$. Oven temperature was from 60 to $220^{\circ} \mathrm{C}$ at a rate of $7^{\circ} \mathrm{C}$ slope per minute. Injector temperature was $280^{\circ} \mathrm{C}$ and detector (FID) temperature was $270^{\circ} \mathrm{C}$ and carrier gas was helium.

\section{Gas chromatography/mass mass spectrometry}

In order to analyze and identify the combinations forming the essential oil, the chromatograph gas set attached to a mass spectrometry, Model Hewlett Packard-5973 was used. The conditions of analysis and specifications of the $\mathrm{GC} / \mathrm{MC}$ set were as follows: Capillary column HP 5MS of $60 \mathrm{~m}$ length, internal diameter of $0.25 \mathrm{~mm}$ and layer thickness of $0.25 \mu \mathrm{m}$, thermal program of oven ( $3 \mathrm{~min}$ ) at $60^{\circ} \mathrm{C}$, then 60 to $220^{\circ} \mathrm{C}$ with a $6^{\circ} \mathrm{C}$ slope per minute, then $3 \mathrm{~min}$ in $220^{\circ} \mathrm{C}$, the temperature of place of injection $280^{\circ} \mathrm{C}$, gas conveying helium, the speed of gas moved by $1.0 \mathrm{ml}$ per minute, the ratio of fission is 1 to 43 , the rate of injection is $0.1 \mu \mathrm{l}$, temperature of the reservoir of ionization is $230^{\circ} \mathrm{C}$, ionization mode $\mathrm{El}$, ionization energy is $70 \mathrm{eV}$. The series of normal Alkans C8-C17 were also injected into the set under the same condition with that of essential oil injection to calibrate retention index (RI) of components of essential oil. The retention index of components of the sample was calculated. Finally, the components of essential oil was identified by comparing the mass spectrums obtained with the existing standard mass spectrums at electronic library of Wiley 2000 existing in Absolution software of GC/Ms set and calculation of standard restrictive index was in accordance with C8-C17 Alkans and when comparing them with the existing standard figurers in literature (Adams, 2001).

\section{Antibacterial assay}

The antibacterial activity of laurel oil on 9 resistant pathogenic bacterial strains such as three Gram positive bacteria Staphylococcus aureus (PTCC = 1431), Staphylococcus epidermidis (PTCC $=1436)$ and Streptococcus faecalis $($ PTCC = 1237) and six Gram negative bacteria Pseudomonas aeroginosa $($ PTCC $=1430)$, Shigella flexneri $($ PTCC $=1716)$, Kellebsiella pneuomoniae (PTCC = 1053), Salmonella typhi $($ PTCC $=1609)$, Serratia marcescens $($ PTCC $=1187)$ and Escherichia coli $($ PTCC $=$ 1533) was determined. The bacteria under experiment were obtained from the Center for Fungi and Bacteria of Iranian Scientific and Industrial Researches Organization. The antibacterial activity of the essential oil was evaluated by disc diffusion method (Baron and Finegold, 1995). The bacteria were cultured for $24 \mathrm{~h}$ on the media of Muller Hinton Agar. A suspension with a dilution of $0.5 \mathrm{Mac}$ Farland at the culture media of Muller Hinton Broth was prepared. Then $1 \mathrm{ml}$ of suspension of each bacteria was cultured using spread plate method. Then, the blank sterile discs containing $30 \mu \mathrm{l}$ of 1.5 dilution of essential oil diluted with DMSO were placed on culture media. The diameters of zones of inhibition of growth after $24 \mathrm{~h}$ of plate incubation at $37^{\circ} \mathrm{C}$ were measured. At that time, the antibacterial impacts of essential oil of sweet bay when compared with tetracycline antibiotic $(8 \mathrm{mg} / \mathrm{ml})$ as evidence was studied. All 
Table 1. Combinations identified in the essential oil of the leaves of $L$. nobilis $L$.

\begin{tabular}{|c|c|c|c|}
\hline Compound no. & Compound name & Restrictive index (RI) & Percentage (\%) \\
\hline 1 & (E)-2-Hexenal & 845 & 1.32 \\
\hline 2 & Tricyclene & 925 & 2.27 \\
\hline 3 & a-Thujene & 928 & 0.38 \\
\hline 4 & a-Pinene & 937 & 5.25 \\
\hline 5 & Camphene & 958 & 3.86 \\
\hline 6 & Sabinene & 983 & 8.7 \\
\hline 7 & $\beta$-Pinene & 1005 & 3.99 \\
\hline 8 & Myrcene & 1018 & 1.68 \\
\hline 9 & a-Phellandrene & 1022 & 0.37 \\
\hline 10 & $\alpha$-Terpinene & 1025 & 2.12 \\
\hline 11 & $P$-Cymene & 1029 & 0.31 \\
\hline 12 & Limonene & 1032 & 3.47 \\
\hline 13 & 1,8-Cineole & 1037 & 25.7 \\
\hline 14 & Y-Terpinene & 1068 & 3.48 \\
\hline 15 & Terpinolene & 1092 & 0.22 \\
\hline 16 & Linalool & 1123 & 1.56 \\
\hline 17 & Sabinol & 1138 & 2.45 \\
\hline 18 & Borneol & 1154 & 2.37 \\
\hline 19 & ঠ-Terpineol & 1175 & 0.19 \\
\hline 20 & Terpinene-4-ol & 1192 & 1.21 \\
\hline 21 & a-Terpineol & 1201 & 3.79 \\
\hline 22 & Bornyl acetate & 1257 & 1.79 \\
\hline 23 & $\mathrm{v}$-Terpinyl acetate & 1321 & 0.24 \\
\hline 24 & Eugenol & 1368 & 1.69 \\
\hline 25 & B-elemene & 1395 & 2.30 \\
\hline 26 & $\beta$-Caryophyllene & 1425 & 0.87 \\
\hline 27 & $\alpha$-Humulene & 1476 & 2.19 \\
\hline 28 & Germacrene A & 1498 & 1.53 \\
\hline 29 & y-Cadinene & 1514 & 2.68 \\
\hline 30 & Germacrene D-4-ol & 1549 & 1.59 \\
\hline 31 & Spathulenol & 1573 & 3.38 \\
\hline 32 & Caryophyllene oxide & 1589 & 0.58 \\
\hline 33 & Humulene epoxid-2 & 1597 & 2.22 \\
\hline Total & & & 95.75 \\
\hline
\end{tabular}

The restrictive index was calculated by injecting the mixture of normal hydrocarbons $\left(\mathrm{C}_{8}-\mathrm{C}_{17}\right)$ into HP-5MS column.

the experiments were carried out in triplicate and averages were calculated for the inhibition zone diameters.

\section{RESULTS}

The study of the analysis of L. nobilis L. essential oil under the present investigation showed that the output ofessential oil was $1.8 \%(\mathrm{v} / \mathrm{w})$. The identified compounds in essential oil, restrictive index (RI) and quantitative percentage of the compounds from leaves are presented in Table 1. Thirty three compounds identified in L. nobilis essential oil, comprises $95.75 \%$, they are 1,8-cineole $(25.7 \%)$, sabinene $(8.7 \%)$ and a-pinene $(5.25 \%)$ with
$39.65 \%$ constituting the highest percentage of essential oil.

Antibacterial activity of essential oil from the leaves of $L$. nobilis $L$. on human pathogenic bacteria by disc diffusion method with measurement of average inhibition zone was studied in the Kerman Province. The antibacterial effects of this essential oil was determined against three Gram positive bacteria: $S$. aureus (PTCC = 1431), S. epidermidis (PTCC $=1436$ ) and $S$. faecalis $($ PTCC $=1237)$ and six Gram negative bacteria: $P$. aeroginosa (PTCC $=1430), S$. flexneri $(\mathrm{PTCC}=1716), K$. pneuomoniae (PTCC $=1053)$, S. typhi $($ PTCC $=1609)$, $S$. marcescens $($ PTCC $=1187)$ and E. coli $($ PTCC $=1533)$. 
Table 2. The results of the antibacterial effects of the essential oil of the leaves of $L$. nobilis $L$.

\begin{tabular}{lcc}
\hline Bacteria & $\begin{array}{c}\text { The diameter of zone of } \\
\text { inhibition of } \mathbf{g r o w t h}(\mathbf{m m})\end{array}$ & $\begin{array}{c}\text { Tetracycline } \\
\text { (8 } \mathbf{~ m} \mathbf{g} \mathbf{m})\end{array}$ \\
\hline Staphylococcus aureus (1431) & 29 & 15 \\
Staphylococcus epidermidis (1436) & 26 & 21 \\
Streptococcus faecalis (1237) & 18 & 16 \\
Pseudomonas aeroginosa (1430) & 24 & 22 \\
Shigella Flexneri (1716) & 27 & 19 \\
Kellebsiella pneuomoniae (1053) & 21 & 14 \\
Salmonella typhi (1609) & 18 & 17 \\
Serratia marcescens (1187) & 26 & 13 \\
Escherichia coli (1533) & 28 & 12 \\
\hline
\end{tabular}

The results of studying the antibacterial impacts shows that the oil of this plant has a 29, 26 and $18 \mathrm{ml}$ diameter of zone of inhibition of growth on positive bacteria of $S$. aureus, and $S$. epidermidis and $S$. faecalis, respectively and has a diameter of zone of inhibition of growth of 24 , $27,21,18,26$ and $28 \mathrm{ml}$ on negative bacteria of $P$. aeroginosa, S. flexneri, K. pneuomoniae, S. typhi, S. marcescens and E. coli, respectively (Table 2). The effect of the essential oil of $L$. nobilis on bacteria tested was more than that of tetracycline antibiotic. The results showed that the essential oil of $L$. nobilis had strong antibacterial effects.

\section{DISCUSSION}

The antibacterial activity of the essential oil of $L$. nobilis $L$. in this study was compared with that of other researches in the world. In a research, the essential oil of $L$. nobilis $L$. exhibited a very strong antibacterial activity against the tested bacteria $(P<0.05)$ (Dadalioglu and Evrendilek, 2004). The results of antimicrobial activity against both Gram positive and negative bacteria species showed that $L$. nobilis induced the highest toxicity at $0.3 \mathrm{mg} / \mathrm{g}$ and affected energy metabolism and oxidative stress (Malti and Amarouch, 2009). In this study, the antibacterial and antifungal activities of $L$. nobilis $L$. (Lauraceae) was investigated. The microbial effect of this plant was tested by a disk diffusion method using Bacillus megaterium DSM 32, Bacillus brevis FMC 3, Bacillus subtilis IMG 22, Bacillus cereus FMC 19, E. coli DM, Enterobacter aerogenes CCM 2531, P. aeruginosa DSM 50071, S. aureus Cowan 1, Listeria monocytogenes Scott $A$ and Micrococcus luteus LA 2971, Candida tropicalis and Candida albicans CCM 314. The results showed that the growth of $S$. aureus was inhibited by this plant extract (Digrak et al., 2001). In a research, eleven ethanolic extract from species of $L$. nobilis was assayed for the in vitro antibacterial activity against 3 Gram positive ( $B$. subtilis, $S$. aureus and $S$. epidermidis) and 2 Gram negative bacteria ( $E$. coli and $P$. aeruginosa), using agar dilution methods. The minimum inhibition concentration
(MIC) of the L. nobilis ethanolic extracts was $5 \mathrm{mg} / \mathrm{mL}$ for all the microorganisms tested (Erturk, 2006). The essential oils from $L$. nobilis (L.) has been characterized and tested against two bacteria (Lactobacillus plantarum and $E$. coli) using a submerged broth culture method. The results obtained showed that $E$. coli was more inhibited than $L$. plantarum by essential oil of $L$. nobilis (L.) (Bouzouita et al., 2003). The antibacterial activity of $L$. nobilis was studied in vitro in tree bacterial strains: $S$. aureus, S. intermedius and K. pneumonia. The major component was 1,8 -cineole $(52.43 \%)$. The bacterial strains tested were found to be sensitive to essential oils studied and showed a very effective bactericidal activity with minimum inhibitory concentrations (MIC) ranging from 0.01 to $1 \mathrm{mg} / \mathrm{ml}$ (Derwich et al., 2009). In a study, the bacteriostatic and bactericidal activities of laurel oil against seven bacteria (Aerobacter aerogenes, $B$. subtilis, E. coli, Proteus vulgaris, Pseudomonas aeruginosa, Staphylococcus albus and $S$. aureus) were evaluated. The results showed that the essential oil tested varied in their antibacterial activity. Laurel oil was active against all tested bacteria (Kivanc and Akgul, 1986). This study was carried out to determine the in vitro antimicrobial activity of the essential oil, seed oil and methanolic extract of seed oil obtained from $L$. nobilis $\mathrm{L}$. (Lauraceae). The methanolic extract of seed oil exhibited more effective antibacterial activity as compared to the essential oil and seed oil. GC-MS analyses of the essential oil resulted in the identification of 25 compounds. 1.8-Cineol (44.72\%), a-terpinyl acetate $(12.95 \%)$ and sabinene $(12.82 \%)$ were the main components. Methanolic extract of seed oil, showed $64.28 \%$ inhibition (Ozcan et al., 2010). Leaf extracts of $L$. nobilis L. showed antimicrobial activity against Grampositive bacteria (S. aureus and S. pyogenes) (Fukuyama et al., 2011). In a research, the essential oil exhibited strong antibacterial activity against all tested foodborne spoilage and pathogenic bacteria (Ramos et al., 2012). In a study, kaempferol glycosides isolated from $L$. nobilis $L$., kaempferol-3-O- $\alpha-L-(2 ", 4$ "-di-E-p-coumaroyl)-rhamnoside (C2) and kaempferol-3-O- $\alpha-L-(2 "-E-p$-coumaroyl-4"-Z-pcoumaroyl)-rhamnoside (C3), showed strong antibacterial 
activities against methicillin-resistant Staphylococcus aureus (MRSA) and vancomycin-resistant enterococci (Liu et al., 2009). An extract from L. nobilis L. (Lauraceae) leaves showed antibacterial activity against methicillin-resistant $S$. aureus (Otsaka et al., 2008). 1,8Cineole laurel oil has antimicrobial activity on several strains of bacteria and yeasts as well as some molds (Akgul et al., 1989).

\section{Conclusion}

The antibacterial properties of the essential oil of $L$. nobilis L. has been studied in other countries but the antibacterial effects of the essential oil of $L$. nobilis $L$. grown in Kerman Province is yet to be studied. The present study results showed that the major oil components of the leaves of $L$. nobilis $L$. from Kerman Province, Iran were 1,8-cineole, sabinene and $\alpha$-pinene which were reported as the main constituents in other areas. The results of this study could be of interest for further phytochemical and biological investigation of $L$. nobilis $\mathrm{L}$. taking into account that 1,8-cineole oil showed marked antimicrobial activity (van Vuuren and Viljoen, 2007). $1,8-C$ ineol is a natural organic compound which is a colorless liquid. It is a cyclic ether and a monoterpenoid with antibacterial effects (Cowan, 1999). 1,8-Cineole was reported as important constituents of $L$. nobilis $L$. $L$. nobilis has a higher antibacterial effect than tetracycline antibiotic. The strong antibacterial activity of $L$. nobilis oil and their components (1,8-cineole, sabinene and $\alpha$ pinene) can be explained by the high percentage of these components in the oil.

\section{ACKNOWLEDGEMENT}

This study was financially supported by the Department of Biodiversity, Institute of Science and High Technology and Environmental Sciences, Graduate University of Advanced Technology with number contract (1.2633) in Kerman. Hereby, the executive and colleagues of the research project express their thanks for the support.

\section{REFERENCES}

Adams RP (2001). Identification of essential oil components by gas chromatography mass spectroscopy. Illinois Allured Publication Corporation.

Akgul A, Kivanc M, Bayrak A (1989). Chemical Composition and Antimicrobial Effect of Turkish Laurel leaf Oil. J. Essent. Oil Res. 1(6):277-280.

Barnes J, Anderson LA, Phillipson DJ, (2002). Herbal Medicines, 2nd edition. London, Pharmaceutical Press. p. 187.

Baron EJ, Finegold SM (1995). Bailey and Scott's Diagnostic Microbiology, 8th ed. Mosby, St. Louis, MO, USA, pp. 171D193.
Bisset NG, Wichtl M (2001). Herbal Drugs and Phytopharmaceuticals: A Handbook for Practice on a Scientific Basis. 2nd edition. Stuttgart, Medpharm: p. 446

Bouzouita N, Kachouri F, Hamdi M, Moncef Chaabouni M (2003). Antimicrobial activity of essential oils from Tunisian aromatic plants. Flavour Frag. J. 18(5):380-383.

Bown D (2001). Encyclopaedia of Herbs and their Uses. pp. 448.

Chiej R (1984). The Macdonald Encyclopedia of Medicinal Plants. London, Macdonald \& Co. p. 274.

Cowan MM (1999). Plant products as antimicrobial agents. Clin. Microbiol. Rev.12:564-582.

Dadalioglu I, Evrendilek GA (2004). Chemical Compositions and Antibacterial Effects of Essential Oils of Turkish Oregano (Origanum minutiflorum), Bay Laurel (Laurus nobilis), Spanish Lavender (Lavandula stoechas L.), and Fennel (Foeniculum vulgare) on Common Foodborne Pathogens. J. Agric. Food Chem. 52(26):82558260.

Derwich E, Benziane Z, Boukir A (2009). Chemical composition and antibacterial activity of leaves essential oil of Laurus nobilis from Morocco. Aust. J. Basic Appl. Sci. 3(4):3818-3824.

Digrak, M, Hakki AM, Ilçim A, (2001). Antibacterial and antifungal activities of Turkish medicinal plants. Pharm. Biol. 39(5):346-350.

Duke JA, Bogenschutz-Godwin MJ, DuCellier J (2002). Handbook of Medicinal Herbs. 2nd edition. Boca Raton, CRC Press. p. 281.

Erturk O (2006). Antibacterial and antifungal activity of ethanolic extracts from eleven spice plants. Biologia 61(3):275-278.

Fukuyama $\mathrm{N}$, Ino $\mathrm{CH}$, Suzuki $\mathrm{Y}$, Kobayashi $\mathrm{N}$, Hamamoto $\mathrm{H}$, Sekimizu K, Orihara $Y$ (2011). Antimicrobial sesquiterpenoids from Laurus nobilis L. Nat. Prod. Res. 25(14):1295-1303.

Grieve M (1984). A modern herbal. Penguin. 919 pp.

Holtom J, Hylton W (1979). Complete Guide to Herbs. Emmaus, Pennsylvania: Rodale Press.

Huxley A (1992). The New RHS Dictionary of Gardening.

Kivanc M, Akgul A (1986). Antibacterial activities of essential oils from Turkish spices and citrus. Flavour Fragr. J. 1(4):175-179.

Lewis WH, Elvin-Lewis MPF (2003). Medical Botany: Plants Affecting Human Health. 2nd edition. Hoboken, Wiley: $495 \mathrm{pp}$.

Liu MH, Otsuka N, Noyori K, Shiota S, Ogawa W, Kuroda T, Hatano T, Tsuchiya T (2009). Synergistic effect of kaempferol glycosides purified from Laurus nobilis and fluoroquinolones on MethicillinResistant Staphylococcus aureus. Biol. Pharm. Bull. 32(3):489-492.

Malti JE, Amarouch H (2009). Antibacterial Effect, Histological Impact and Oxidative Stress Studies from Laurus nobilis Extract. J. Food Qual. 32(2):190-208.

Otsaka N, Liu MH, Shiota S, Ogawa W, Kuroda T, Hatano T, Tsuchiya T (2008). Anti-methicillin resistant Staphylococcus aureus (MRSA) compounds isolated from Laurus nobilis. Biol. Pharm. Bull. 31(9):1794-1797.

Ozcan B, Esen M, Kemal SM, Coleri A, Caliskan M (2010). Effective antibacterial and antioxidant properties of methanolic extract of Laurus nobilis seed oil. J. Environ. Biol. 31(5):637-641.

Phillips R, Foy N (1990). Herbs: How to grow or gather herbal plants and use them for cookery, health and beauty. Pan Macmillan. $192 \mathrm{pp}$.

Ramos C, Teixeira B, Batista I, Matos O, Serrano C, Neng NR, Nogueira JMF, Nunes ML, Marques A (2012). Antioxidant and antibacterial activity of essential oil and extracts of bay laurel Laurus nobilis Linnaeus (Lauraceae) from Portugal. Nat. Prod. Res. 26(6):518-529.

Van Vuuren, SF, Viljoen AM (2007). Antimicrobial activity of limonene enantiomers and 1,8-cineole alone and in combination. Flavour Fragr. J. 22(6):540-544.

Weiss RF, Fintelmann V (2000). Herbal Medicine. 2nd. edition. Stuttgart, Thieme: 214. 